\title{
І.Г. Маркович
}

\section{ДИНАМІКА ЗАХВОРЮВАНОСТІ ТА ПОШИРЕНОСТІ ІНФЕКЦІЙНИХ ХВОРОБ В УКРАЇНІ}

\author{
Науково-координаційне управління Апарату Президії Національної академії медичних наук України
}

Висвітлено питання інфекційної захворюваності в Україні за класами хвороб, згідно з Міжнародною класифрікацією хвороб $X$ перегляду (МКX-10), а також за даними галузевої статистичної звітності санітарноепідеміологічної служби. Визначені загальні тенденції та регіональні особливості у динаміці найважливіших епідпоказників.

Ключові слова: захворюваність, поширеність, епідеміологія.

Серед людей та тварин циркулює безліч мікроорганізмів, зокрема збудників небезпечних та особливонебезпечних інсекцій. Деякі патогени мають давню історію, інші - лише на початку свого розвитку. Однак всі вони заслуговують на увагу як дослідників, так і пересічних людей, оскільки перші повинні, вивчивши властивості бактерій чи вірусів, запропонувати методи боротьби з ними, інші - навчитись елементарних правил захисту від біологічних «паразитів».

В Україні щорічно за медичною допомогою звертаються мільйони людей, реєструється 8-9 млн випадків інсрекційних хвороб. Найбільше впливають на стан здоров'я населення грип і гострі респіраторні інсрекції, вірусні гепатити, туберкульоз, ВІЛ/СНІД, інфрекції, керовані засобами специфічної профілактики, паразитози [1-3]. Разом з тим, існує величезна кількість хворих, які через ряд обставин не звертаються до медичних працівників за допомогою і не потрапляють до офріційної статистики.

Метою даного дослідження було вивчення інсрекційної захворюваності населення України в динаміці за 20 років.

\section{Матеріали і методи}

Проаналізовано дані статистичних звітів медичних закладів і Центру медичної статистики МОз України, а також матеріали галузевої звітності Державної санітарноепідеміологічної служби за 1994-2013 рр. Під час виконання даного дослідження використано широко відомі та вживані статистичні методи [1-3].

\section{Результати досліджень та їх бговорення}

До переліку показників, які різнобічно характеризують здоров'я населення і підлягають динамічному спостереженню та аналізу, належать захворюваність і поширеність хвороб, їх статево-вікові, територіальні особливості тощо. В даній роботі проаналізовано загальні тенденції захворюваності та поширеності хвороб за всіма класами та за Класом I. МКХ-10 «Деякі інфекційні та паразитарні хвороби».

Проведений ретроспективний аналіз дозволив констатувати, що в Україні з високим рівнем достовірності $\left(R^{2}=0,95\right)$ спостерігається погіршення стану здоров'я населення, про що свідчать показники поширеності хвороб серед всього населення (мал. 1).

У найближчі роки можна очікувати подальшого збільшення кількості випадків захворювань за всіма класами хвороб. Прогнозні значення можуть сягати від 205975,2 випадків на 100 тис. відповідного населення у 2015 р. до 226128,2 випадків у 2020 р., при тому, що в 1994 р. цей показник складав лише 119711,1 випадків.

Стосовно динаміки показників первинної захворюваності можна припустити, що в наступні 5-6 років цей показник теж продовжуватиме зростати. Прогнозні значення складатимуть від 73498,4 у 2015 р. до 76216,9 випадків на 100 тис. відповідного населення у 2020 р. (фоктичний показник у 1994 р. становив 60582,2 випадки, мал. 2).

Таким чином, за 20 років спостереження (19942013 рр.) показник поширеності хвороб (за всіма класами) серед всього населення зріс на 55,1 \%, що свідчить про накопичення випадків хронічної патології. Показник первинної захворюваності змінився не так глобально лише на $12,9 \%$.

Причинами цих змін можуть бути об'єктивні чинники, які сприяють зростанню поширеності хвороб, зокрема, завдяки подовженню тривалості життя відбувається збільшення частки осіб старшого віку, для яких притаманно накопичення хронічної патології, а також, можливо, певне підвищення доступності та якості надання медичної допомоги. 
ОРИГІНАЛЬНІ ДОСЛІДЖЕННЯ

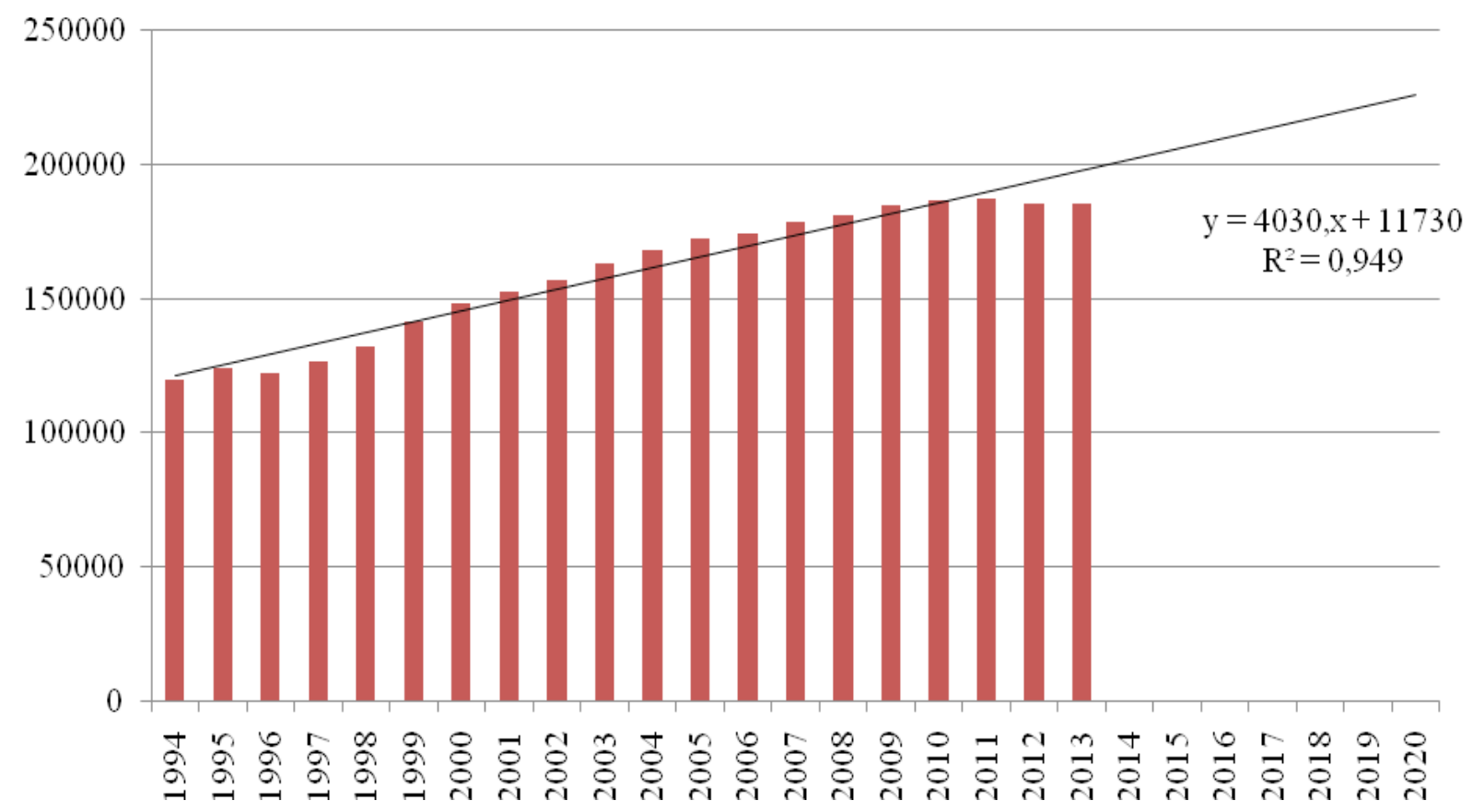

Мал. 1. Динаміка поширеності хвороб за всіма класами серед населення України за 1994-2013 рр. (на 100 тис. нас.) та прогноз до 2020 р.

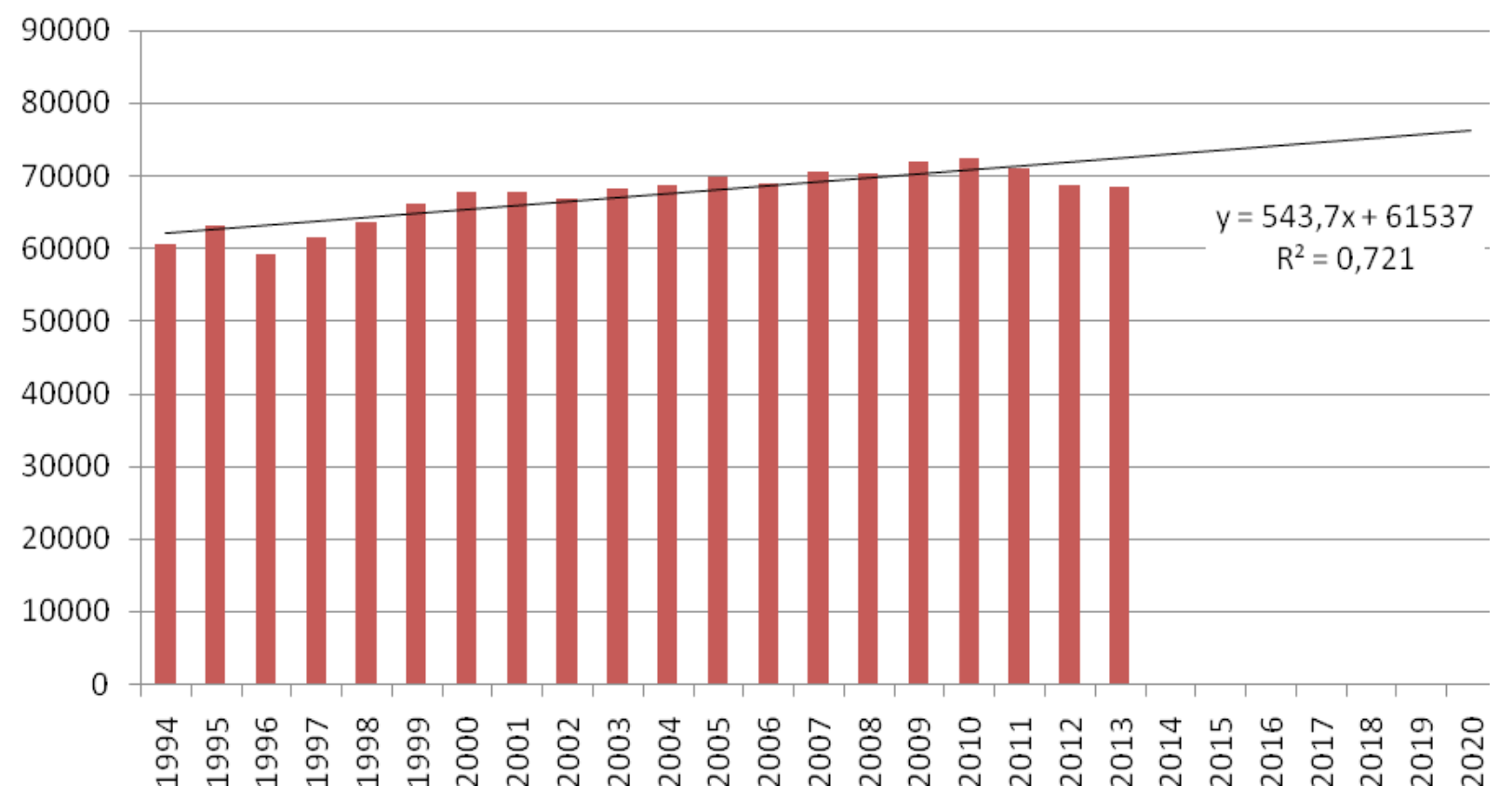

Мал. 2. Динаміка захворюваності за всіма класами серед населення України за 1994-2013 рр. (на 100 тис. нас.) та прогноз до 2020 р.

Стосовно Класу І. МКХ-10 «Деякі інфрекційні та паразитарні хвороби» спостерігалась протилежна ситуація
- відбулось зниження показників захворюваності та поширеності на 7,2 та 11,9 \% відповідно (мал. 3). 


\section{ОРИГІНАЛЬНІ ДОСЛІДЖЕННЯ}

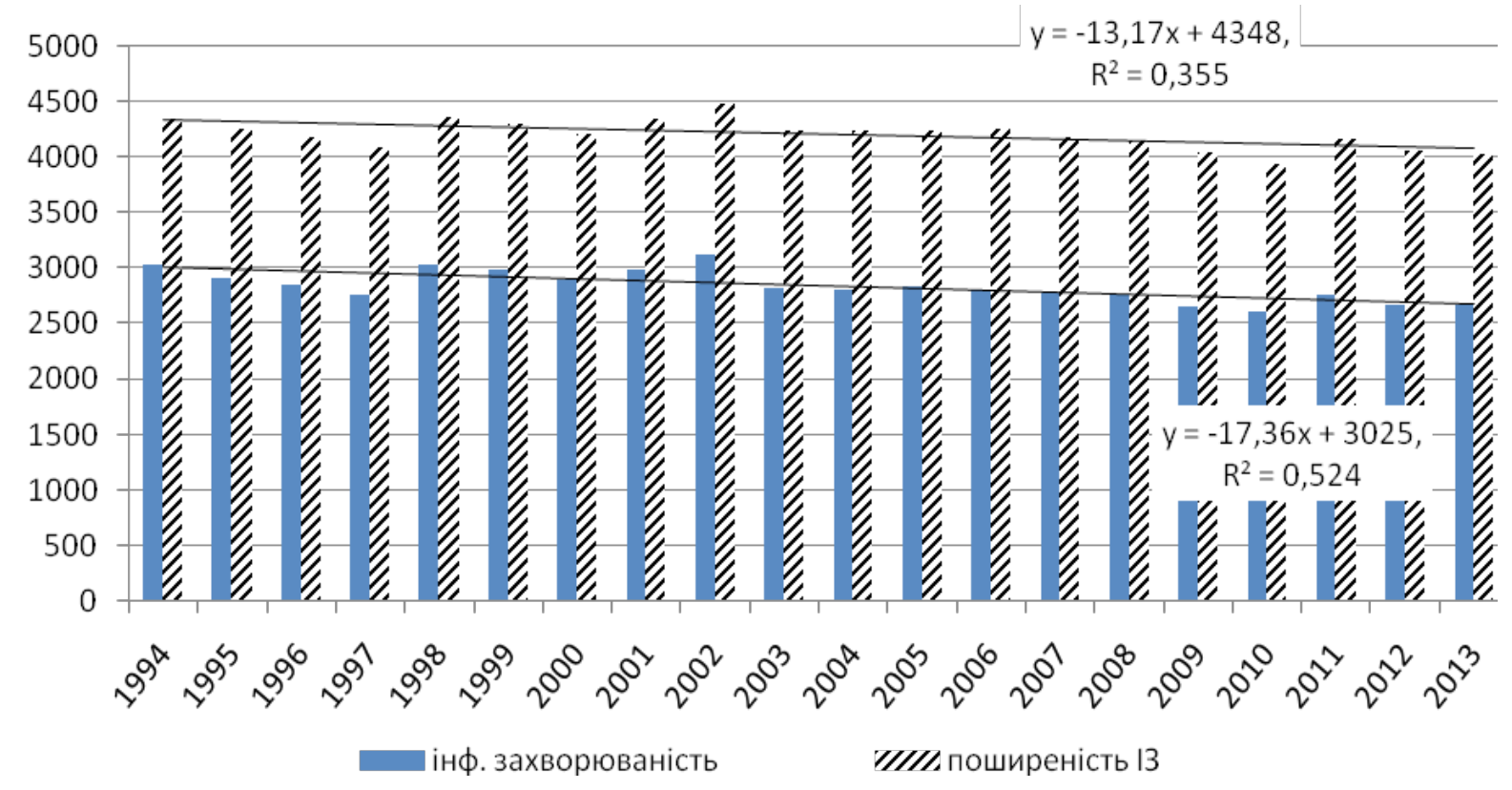

Мал. 3. Динаміка захворюваності та поширеності хвороб, віднесених до класу «Деякі інфекційні та паразитарні хвороби», протягом 1994-2013 рр. (на 100 тис. нас.).

Якщо у 1994 р. було зареєстровано серед всього населення понад 2,25 млн випадків інфекційних хвороб (4350,7 на 100 тис. відповідного населення), то у 2013 - трохи більше 1,83 млн випадків (4038,8 на 100 тис. відповідного населення). Показники поширеності деяких інфекційних і паразитарних хвороб коливались від 4493,3 випадків у 2002 р. (максимальний показник) до 3948,7 випадків на 100 тис. населення у 2010 р. (мінімальний показник).

В 1994 р. до класу «Деякі інфекційні та паразитарні хвороби» було включено 1,58 млн випадків вперше виявлених хвороб (3043,4 на 100 тис. відповідного населення), у 2013 р. цей показник зменшився до 1,21 млн випадків $(2680,9)$. Протягом періоду, що аналізувався, показники первинної інфекційної та паразитарної захворюваності перебували в межах від 3129 випадків (2002 р., максимальний показник) до 2611,2 випадків на 100 тис. населення (2010р., мінімальний показник).

Питома вага інсрекційних і паразитарних хвороб серед усіх виявлених та зареєстрованих захворювань (за всіма класами хвороб) протягом останніх років не перевищувала 4-5 \%, зокрема, в 1994 р. складала 3,6 \%, a у 2013 р. $-2,2 \%$.

Незважаючи на певні коливання у показниках захворюваності та поширеності у бік їх зростання чи зниження (показники достовірності апроксимації складають $R^{2}=0,5$ та $R^{2}=0,4$, відповідно), рівень інфекційної та паразитарної захворюваності залишається достатньо стабільним, що обумовлено безперервною циркуляцією серед населення збудників цих хвороб. А тому інфекційні хворі вимагають постійної уваги 3 боку організаторів системи охорони здоров'я. 3 числа всіх осіб, які перебували під диспансерним наглядом на кінець 2013 р., 1,9 \% припадало на хворих з інсекційною патологією.

Аналіз територіального розподілу виявлених випадків показав, що на початку спостереження (1994р.) в 11 областях показники поширеності «деяких інфекційних та паразитарних хвороб» перевищували середній по країні (Волинська, м. Київ, Дніпропетровська, Житомирська, Черкаська, Полтавська, Кіровоградська, Донецька, Миколаївська області, АР Крим та м. Севастополь). Найбільший внесок у поширеність інфекційної та паразитарної захворюваності зробили Дніпропетровська область (питома вага зареєстрованих випадків складала 8,1 \%), Донецька (11,6 \%), АР Крим (5,3 \%), Луганська, Львівська, Одеська області та м. Київ та Севастополь (по 5 \%). Лідирували АР Крим (пок. 5400,0), Миколаївська область $(5904,0)$ та м. Севастополь $(7256,4)$ при загальнодержавному показнику 4350,7 випадків на 100 тис. населення.

Протягом цього ж періоду первинна захворюваність була вищою у 12 регіонах: Запорізькій, Житомирській, Одеській, Донецькій, Дніпропетровській, Черкаській, Полтавській, Кіровоградській, Миколаївській областях, АР Крим, м. Київ та Севастополь. 


\section{ОРИГІНАЛЬНІ ДОСЛІДЖЕННЯ}

У 2013 р. перевищували загальнодержавний (4038,8 випадків на 100 тис. населення) показники поширеності хвороб у 12 регіонах (Херсонській, ІваноФранківській, Харківській, Кіровоградській, Запорізькій, Миколаївській, Волинській, Одеській, Донецькій, Дніпропетровській областях, АР Крим і м. Севастополь).

Показник вперше виявленої інфекційної та паразитарної захворюваності був вищим у 14 регіонах і складав від 2,6 до 3,4 тис. випадків на 100 тис. населення, зокрема в Запорізькій, Львівській, Херсонській, Луганській, Житомирській, Миколаївській, Івано-Франківській, Донецькій, АР Крим, Волинській, Одеській, Дніпропетровській областях та м. Севастополь і Київ. В Одеській, Львівській, Дніпропетровській, Івано-Франківській областях і м. Києві спостерігались як високі показники за всіма класами хвороб, так і за класом «Деякі інфекційні та паразитарні хвороби».

Дослідження ступеня кореляції між інфрекційною та паразитарною захворюваністю і загальним показником захворюваності населення (за всіма класами) показало, що між ними існує певний зв'язок, однак слабкий $(r=0,09)$. Тобто, на фрормування захворюваності населення України значно більший вплив мають хвороби неінфекційної етіології, зокрема системи кровообігу, органів дихання, новоутворення та ін. Інфекційна патологія, переважно, має гострий перебіг і менший відсоток випадків розвитку ускладнень чи переходу в хронічний процес, про що свідчать нижчі, ніж в інших класах, показники поширеності хвороб.

Разом з тим, аналіз показників первинної захворюваності серед всього населення та окремих груп, зокрема дорослого працездатного населення та осіб похилого віку, виявив, що, незважаючи на загальну тенденцію до зниження, серед осіб похилого віку спостерігається достовірне збільшення випадків вперше виявленої інфекційної та паразитарної патології (величина достовірності апроксимації складає $\left.\mathrm{R}^{2}=0,9\right)$ (мал. 4). Крім того, можна стверджувати, що захворюваність серед осіб похилого віку суттєво впливає на фрормування показника інфекційної та паразитарної захворюваності, про що свідчить коефріцієнт кореляції $(r=0,74)$.

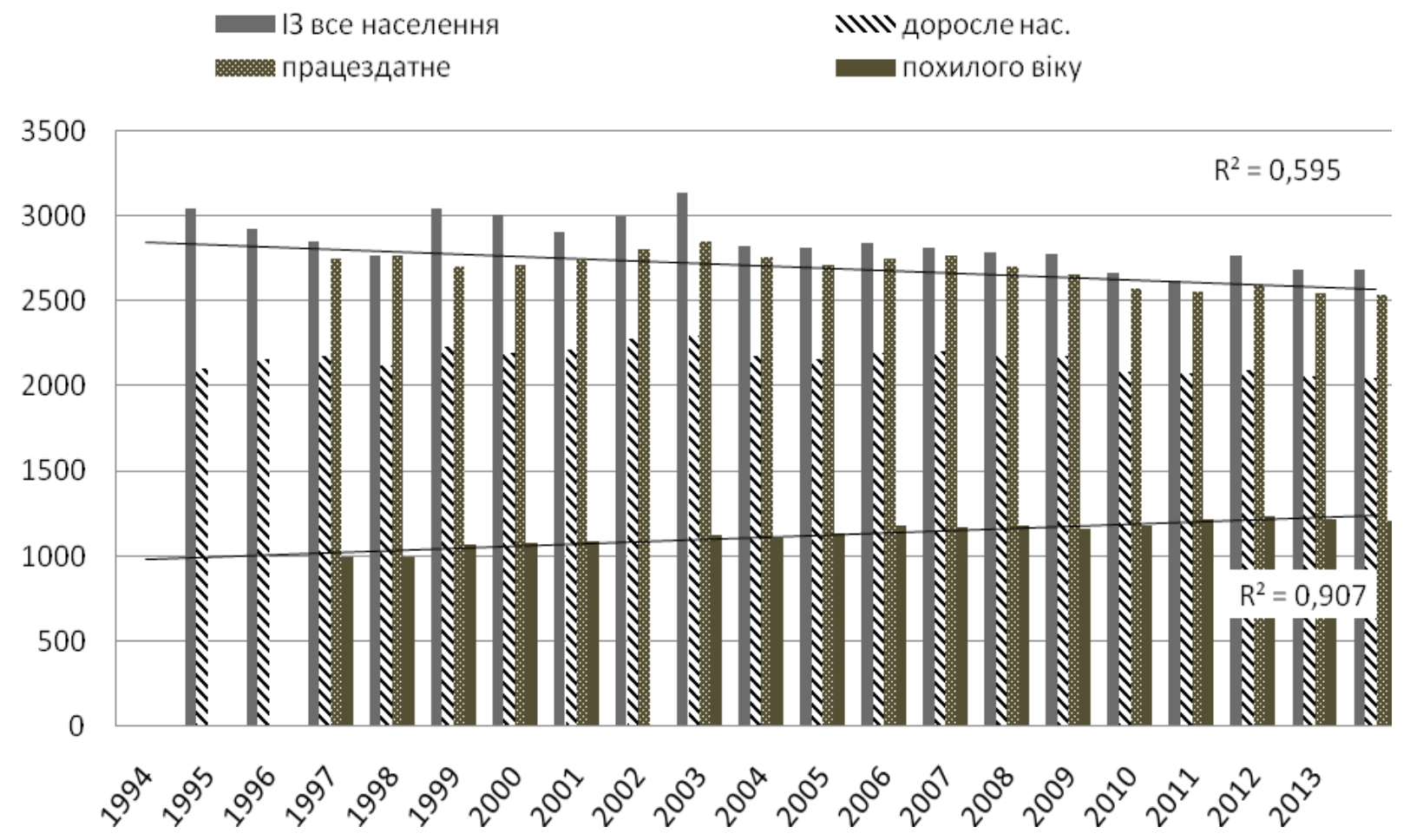

Мал. 4. Динаміка інфекційних захворювань серед усього, дорослого, працездатного населення та осіб похилого віку протягом 1994-2013 рр. (показник на 100 тис. населення).

Дослідження захворюваності у багаторічній динаміці показали, що у розрізі регіонів найбільша амплітуда показників інфекційної захворюваності спостерігалась у Сумській області, де максимальний показник пере- вищував мінімальний у 1,9 разу, Полтавській $(1,8)$, Закарпатській $(1,7)$, Черкаській $(1,7)$, Запорізькій $(1,6)$ та м. Севастополь (у 2 рази). 


\section{ОРИГІНАЛЬНІ ДОСЛІДЖЕННЯ}

Висока поширеність інфекційної та паразитарної захворюваності за 20 років спостереження була притаманна AP Крим, Волинській, Дніпропетровській, Донецькій, Житомирській, Миколаївській, Одеській, Івано-Франківській областям та м. Севастополь. Найнижчі показники мали місце в Закарпатській та Тернопільській областях.

Через те, що випадки інорекційних захворювань реєструються в декількох статистичних формах у закладах системи охорони здоров'я та санітарно-епідеміологічної служби, підходи до формування цих звітних форм різняться. Зокрема, до Центру медичної статистики МО3 України надходять статистичні звіти, згідно яких вся патологія розподіляється по 21 класу. До переліку хвороб, віднесених до Класу 1 [АОО В99] «Деякі інорекційні та паразитарні хвороби», не входять грип та гострі респіраторні інорекції, натомість включаються вірусні інфекційні хвороби, які характеризуються ушкодженням шкіри та слизових оболонок; вірусний гепатит; хвороба, зумовлена вірусом імунодефіциту людини (ВІЛ); інші вірусні хвороби; мікози; протозойні хвороби; гельмінтози; педикульоз, акаріаз та інші інорестації; наслідки інорекційних і паразитарних хвороб; бактеріальні, вірусні та інші інорекційні агенти; тощо.

Гострі респіраторні захворювання верхніх дихальних шляхів, грип та пневмонія, інші гострі респіраторні інфекції нижніх дихальних шляхів, гнійні захворювання нижніх дихальних шляхів та інші входять до Класу 10 [J00 J99] «Хвороби системи дихання». І слід зазначити, що в останні декілька років спостерігається збільшення частки хвороб, які віднесені до цього класу.

Для обліку випадків інфрекційних хвороб у закладах Державної санітарно-епідеміологічної служби використовуються інші фрорми звітності, зокрема № 1 «Звіт про окремі інфекції та паразитарні захворювання за _ місяць 20_ року» (місячна), затв. наказом МОЗ України від 02.06.2009 р. № 378. До цієї фрорми входять грип та ГРІ, однак в них відсутні, наприклад, мікози чи наслідки інфекційних і паразитарних хвороб.

Базовим документом, який тривалий час визначав порядок обліку окремих інфекційних та паразитарних захворювань, був наказ № 654 від 13.12.1989 р. М3 СРСР «О совершенствовании системы учета отдельных инфекциионных и паразитарных заболеваний», яким затверджувався перелік хвороб, які підлягали персональному та сумарному обліку в медичних закладах; регламентовано яким чином і в які терміни надсилалась інсрормація про виявлених хворих та носіїв до територіальних санітарно-епідеміологічних станцій; облікові фрорми та ін. Пізніше Постановою Кабінету Міністрів України (від 21 лютого 2001 р. № 157) було затверджено перелік інорекційних хвороб, щодо яких заклади та установи охорони здоров'я подають статистичну звітність (всього близько 60 позицій разом з випадками носійства).
Згідно із статистичними звітами санітарно-епідеміологічної служби, протягом останніх 20 років спостереження інфекційні хвороби щорічно вражали від 7 до 10 млн мешканців України, діапазон показників захворюваності з урахуванням носіїв, грипу та ГРІ складав від 21975,11 випадків у 1995 р. до 16594,90 вип. на 100 тис. населення у 2006 р.

Без носіїв, грипу та ГРЗ показники захворюваності були значно нижчими і перебували в межах від 1212,86 вип. у 1994 р. до 502,81 вип. на 100 тис. населення у 2013 р. Питома вага інфекційної захворюваності без носіїв, грипу та ГРІ у загальній структурі захворюваності складала від 6,6 та 6,8 \% в 1994 і 1996 рр. відповідно до 2,9 \% у 2013 р. Позитивна динаміка спостерігалась як по відношенню до показників загальної інфекційної захворюваності, так і групи хвороб, яка не включала носіїв, хворих на грип та ГРІ. На мал. 5 показано динаміку інфекційної захворюваності населення України за 20річний період: всього, без грипу і ГРІ та серед дітей.

Частка дитячої інорекційної захворюваності у загальній структурі захворюваності складала від 49,1 \% в 1995 р. до 65,4 \% у 2013 р., спостерігається чітка тенденція до росту даного показника. Однак подібна ситуація може бути пов'язана не лише із дійсним ростом захворюваності серед дітей, а й з тим, що з 2010 р. до вікової групи «діти» включили підлітків 15-17 років.

Динаміка даних темпу росту (зниження) та приросту (спаду) показників захворюваності при базисній основі засвідчила достатньо достовірне $\left(R^{2}=0,83\right)$ зниження активності епідпроцесу протягом даного періоду спостереження.

У розрізі інорекцій, протягом 1994-2013 рр., стійка тенденція до росту показників захворюваності була притаманна кашлюку, інфекційному мононуклеозу, вірусному менінгіту, вітряній віспі, туберкульозу та скарлатині. 32011 р. спостерігається ріст спорадичної та групової захворюваності на менінгококову інфекцію, краснуху, кір. Актуальними залишаються сальмонельози та гастроентероколіти невстановленої етіології. Значне поширення мають туберкульоз, ВІЛ-інфекція та вірусні гепатити. Продовжується зростання показників захворюваності на хворобу Лайма.

Таким чином, зіставлення показників інфекційної та паразитарної захворюваності різних статистичних форм (за класами хвороб та фрорми №1) показало, що різниця між ними сягала від 2,4 разу в 1995 р. до 5,3 - у 2008 та 2013 рр.

Якщо аналізувати фрорму № 1, то можна стверджувати $з$ достатньо високим рівнем вірогідності (величина достовірності апроксимації тренду складає $\left.R^{2}=0,86\right)$, що спостерігається чітка тенденція до зниження інфекційної захворюваності. Однак, якщо проаналізувати лінію тренду показників за класами хвороб, то ця тенденція не така очевидна (мал. 6). 


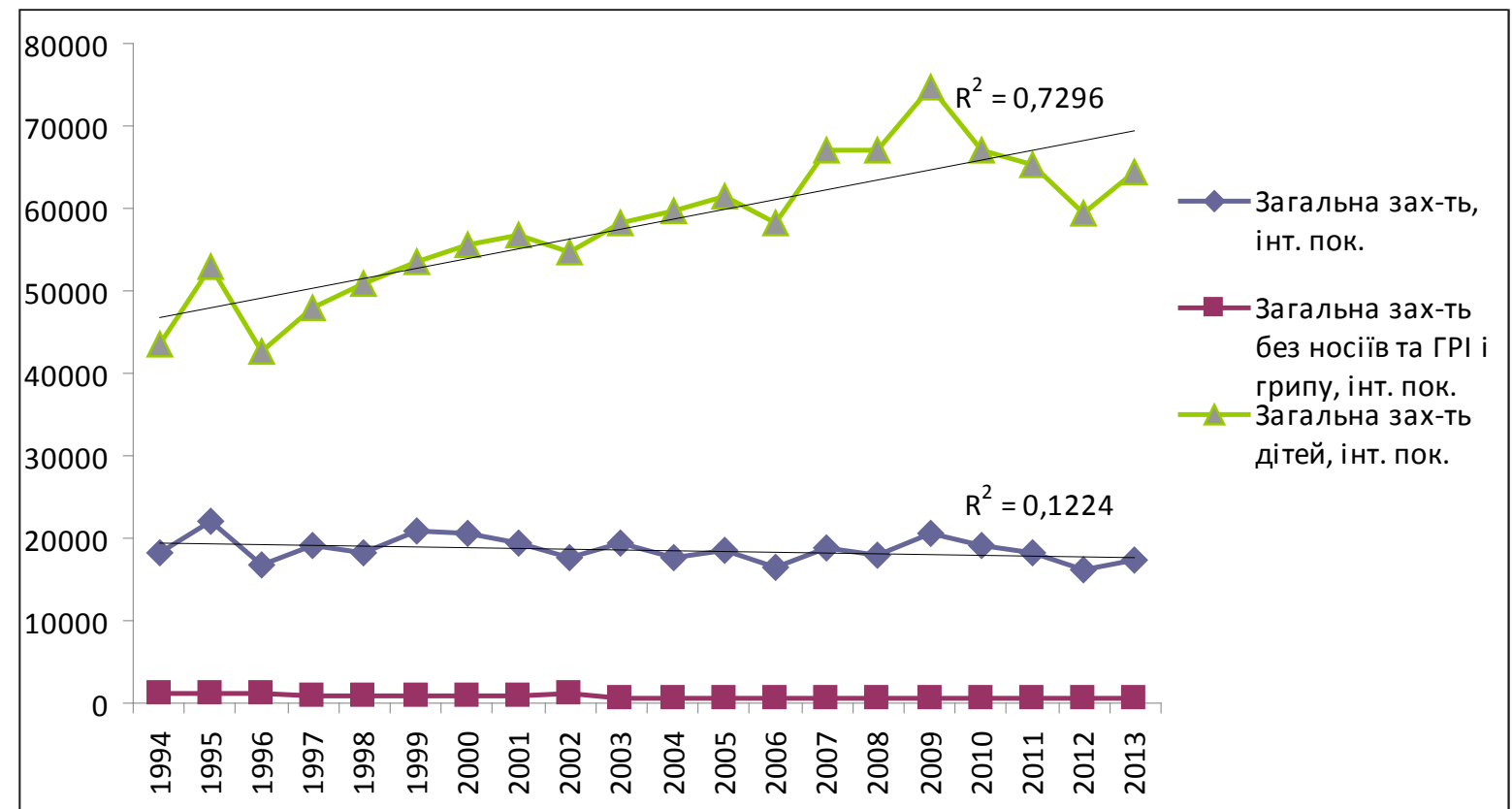

Мал. 5. Динаміка інфекційної захворюваності населення України за 1994-2013 рр. (інтенсивні показники).

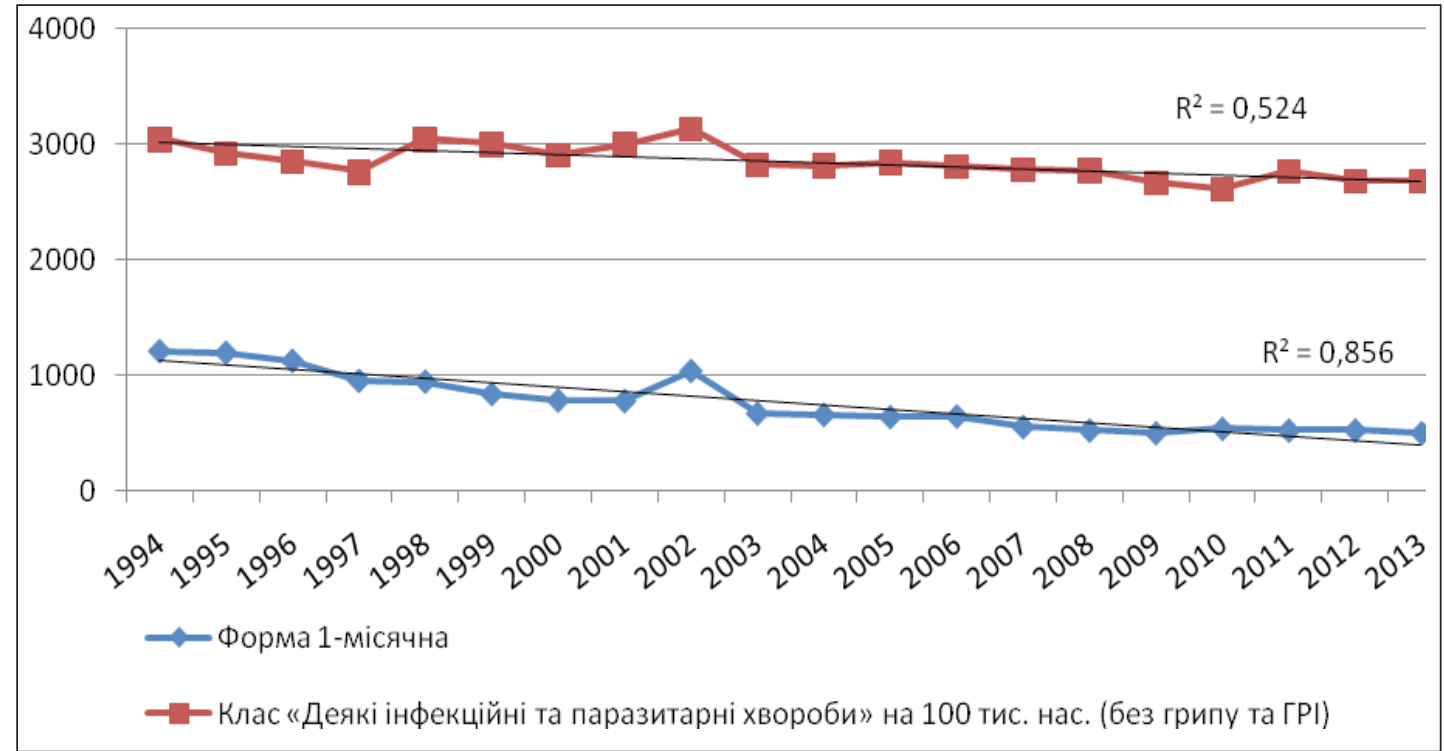

Мал. 6. Динаміка показників інфекційної захворюваності за 1994-2013 рр. (згідно з різними статистичними срормами), у показниках на 100 тис. населення.

Звичайно, фрахівці санепідслужби обліковують лише хворих з інфекційною та паразитарною патологією, щодо яких проводиться комплекс профрілактичних та протиепідемічних заходів і які представляють найбільшу загрозу для осіб, контактних $з$ ними. Однак саме ця розбіжність у показниках, особливо за умови внесення даних про випадки захворювань, обумовлених різноманітними мікроорганізмами, до багатьох інших класів хвороб, зумовлює появу ілюзії про зменшення ролі збудників інфрекційних хвороб у виникненні різноманітної патології, а відповідно і про недоцільність вкладання коштів у розвиток профрілактичного напрямку медицини.

Отже, для забезпечення реальної оцінки рівня поширеності та динаміки інорекційної та паразитарної захворюваності вкрай важливо 
науково обґрунтувати засади фрормування сучасної статистичної звітності. Лише дійсні показники захворюваності дозволяють адекватно оцінювати ризики, обумовлені інфекційними патогенами, та визначати необхідний об'єм профрілактичних і протиепідемічних заходів.

\section{Висновки}

1. В Україні показники захворюваності та поширеності хвороб серед населення, зокрема інфекційної етіології, залишаються достатньо високими, що свідчить про необхідність удосконалення системи надання медичної допомоги, доцільність пропагування та економічного стимулювання здорового способу життя.

2. Для обліку випадків хвороб інфекційної та паразитарної етіології використовується декілька різних статистичних фоорм, а тому з метою отримання достовірної інформації про захворюваність і проведення адекватного аналізу даних доцільно переглянути підходи до фрормування статистичної звітності в різних установах системи охорони здоров'я.

3. Під час реформування медичної галузі, зокрема й санітарно-епідеміологічної служби, слід враховувати, що проведення ефективного епідеміологічного нагляду за інфекційними хворобами, зокрема соціально значимими, і забезпечення біобезпеки населення залишаються одним з пріоритетних завдань держави.

\section{Література}

1. Статистичні звіти медичних закладів та Центру медичної статистики МОЗ України за 1991-2013 рр.: [Електронний ресурс] / Режим доступу: medstat.gov.ua

2. Статистика захворювань. Оперативна інфрормація: [Електронний ресурс] /Режим доступу: http://www.moz.gov.ua/

3. Галузева звітність Державної санітарно-епідеміологічної служби України («Звіт про окремі інфрекційні та паразитарні захворювання», фр. № 1): [Електронний ресурс] /Режим доступу: http://www.dsesu.gov.ua/ua/

\section{DYNAMICS OF MORBIDITY AND PREVALENCE OF INFECTIOUS DISEASES IN UKRAINE}

I.H. Markovych

SUMMARY. The article highlights the problem of infectious morbidity in Ukraine by the types of diseases, according to the International Classification of Diseases, 10th Revision (ICD-10), and also according to the sectoral statistical reporting data of the SanitaryEpidemiological Service. The general tendencies and regional peculiarities of majorepidemiological parameters have been determined.

Key words: morbidity, prevalence, epidemiology.

Отримано 29.02.2015 p.

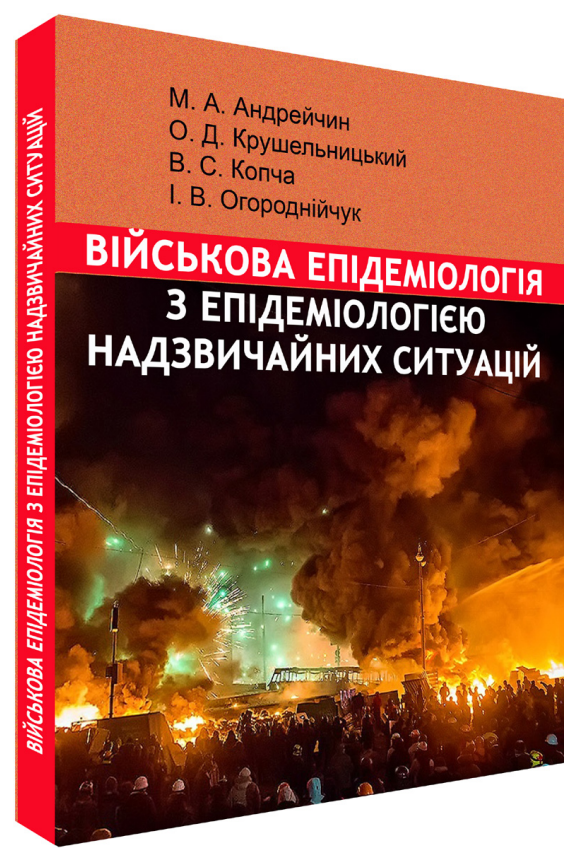

\section{виходить 3 дРукУ новий пІдручник!}

Військова епідеміологія 3 епідеміологією надзвичайних ситуацій: підручник для студентів вищих навчальних закладів IV рівня акредитації I М.А. Андрейчин, О.Д. Крушельницький, В.С. Копча, І.В. Огороднійчук. Тернопіль: Укрмедкнига, 2015. - 315 с.

У підручнику розглянуто взаємозв'язок соціальних і природних чинників, їх вплив на епідемічний процес серед особового складу військ і цивільного населення. Розкрито властивості біологічної зброї, особливості перебігу штучно викликаного епідемічного процесу, планування протиепідемічних заходів в екстремальних умовах. Теоретичні узагальнення проілюстровані епідемічними ускладненнями під час недавніх війн, техногенних аварій та інших надзвичайних ситуацій.

Видання відповідає програмі, затвердженій Міністерством охорони здоров'я України, й адресується студентам медичних навчальних закладів IV рівня акредитації, а також військовим лікарям та іншим медичним працівникам.

3 питань придбання звертатися у ДВНЗ «Тернопільський державний медичний університет ім. І.Я. Горбачевського МОЗ України», Майдан Волі, 1, м. Тернопіль, 46001. Тел. +38 0352 43-49-56. 